\title{
ANALYZING CHEMICAL KINETICS OF COAL GASIFICATION IN MINI GASIFIER REACTOR
}

\author{
ANALISIS KINETIKA REAKSI GASIFIKASI BATUBARA PADA \\ REAKTOR GASIFIKASI MINI
}

\author{
M. ADE A. EFENDI and YENNY SOFAETI \\ R\&D Centre for Mineral and Coal Technology \\ Jalan Jenderal Sudirman 623 Bandung 40211 \\ Phone (+6222) 6030483, Fax. (+6222) 6003373 \\ e-mail: ade.andriansyah@tekmira.esdm.go.id
}

\begin{abstract}
Coal gasification is a chemical reaction that has a purpose to change the original solid coal into gaseous compounds. Converting the coal into gaseous compounds will make the combustion process easier and results in increasing combustion efficiency. The sulfur and nitrogen are also easier to be separated in order to obtain cleaner flue gas. This paper presents kinetic analysis of coal gasification reactions in mini gasifier (or known as GasMin in Bahasa) reactor. The results show that the increase of the air-coal ratio (ACR) affected the maximum temperature of the reactor, which means that an increase of the intake air flow rate will increase the amount of oxygen for combustion reaction. Meanwhile, the increase of the team coal ratio (SCR) will increase flow rate of the mixture of air-steam feed. As a result, the ability of coal gasification has also increased. This will increase gasification efficiency around 3-5\% which then will also increase the gas yield. The maximum value of SCR was 0.06 , further than that of the yield gas and the qvalue will slightly decrease. The simulation result showed that the producer gas was dominated by $\mathrm{CO}$ with $26.72 \%$ mole fraction; $\mathrm{H}_{2}$ with $14.06 \%$ mole fraction, and $\mathrm{N}_{2}$ with $47.88 \%$ mole fraction. Meanwhile $\mathrm{CO}_{2}, \mathrm{CH}_{4}$ and $\mathrm{O}_{2}$ mole fraction were $5 \%, 0.24 \%$, and $1.20 \%$ respectively.
\end{abstract}

Keywords: coal, gasification, mini gasifier, kinetic reactions.

\begin{abstract}
ABSTRAK
Gasifikasi batubara adalah reaksi kimia yang bertujuan untuk mengubah batubara padat menjadi senyawa gas. Dengan mengubah batubara menjadi senyawa gas, proses pembakaran menjadi lebih mudah sehingga efisiensi pembakaran meningkat. Sulfur dan nitrogen juga lebih mudah dipisahkan sehingga mendapatkan produk pembakaran yang bersih. Makalah ini menyajikan analisis kinetika proses gasifikasi batubara pada reaktor gasifikasi mini (GasMin). Hasil penelitian menunjukkan bahwa peningkatan rasio udara-batubara (ACR) mempengaruhi suhu maksimum reaktor, yang berarti peningkatan laju aliran massa udara masuk akan meningkatkan jumlah oksigen yang tersedia untuk reaksi pembakaran. Sementara itu, peningkatan nilai rasio uap batubara-batubara (SCR) akan meningkatkan laju campuran udara-uap; kemampuan untuk gasifikasi batubara juga akan meningkat. $\mathrm{Hal}$ ini menyebabkan meningkatkan efisiensi gasifikasi, sekitar 3-5\% yang akan meningkatkan gas hasil. Nilai maksimum SCR adalah 0,06, lebih dari itu gas hasil dan q-nilai yang sedikit akan berkurang. Hasil simulasi menunjukkan bahwa gas produser didominasi oleh CO dengan fraksi mol

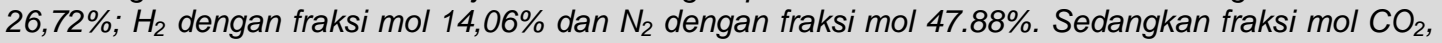
$\mathrm{CH}_{4}$ dan $\mathrm{O}_{2}$ beruturut-turut adalah $5 \% ; 0,24 \%$ dan $1,20 \%$.
\end{abstract}

Kata kunci: batubara, gasifikasi, gasifier mini, kinetika reaksi.

\section{INTRODUCTION}

The energy consumption in Indonesia increases while the policy of oil subsidy has been abolished. Hence, it is necessary to develop affordable and sustainable non-oil energy. Coal is one of the energy resources that is useful to solve the energy crisis (Jang 
et al., 2013) and is ready to be used in terms of the availability and technology. However, environmental impact becomes important issues that hinder the success of coal as an alternative energy. Therefore, utilization technology should be developed to produce clean and efficient energy, both as a direct or indirect burning.

Coal gasification is a process to utilize coal energy without the conventional combustion. The coal is gasified and its gas product is used as a feedstock for numerous end-use products. Potential end-uses include power generation, liquid fuels and chemical feedstock (Skodras et al., 2015). The kinetic rates and extents of the gasification process vary and typically serve as functions of temperature, pressure, reactor and configuration, gas composition, and the nature - chemical composition and properties - of the coal being gasified (Muller et al., 2003; Slavinskaya et al., 2009; Speight, 2013a; Speight, 2013b). Generally, the reaction rate (i.e., the rate of coal conversion) is higher at higher temperatures, whereas reaction equilibrium may be favored at either higher or lower temperatures, depending on the specific type of gasification reaction (Speight, 2015).

Numerous studies have dealt with the kinetic model of coal gasification. He et al. (2013) has developed a steady state kinetic model for an industrial- scale pressurized Lurgi gasifier using the simulator Aspen Plus. The thermodynamic efficiencies of the gasifier and the entire gasification system have been investigated in considerable detail via simulation studies. The simulation results show that the oxygen/coal ratio exerts a strong impact on the exegetic efficiency profile of the combustion zone within the Lurgi gasifier. Gomez and Mahinpey (2015) conduct study that demonstrates a consistent method to perform gasification in the chemically controlled temperature range between $750^{\circ} \mathrm{C}$ and $900^{\circ} \mathrm{C}$. In addition, the apparent activation energy was estimated independent of the kinetic model. The effect of coal bed thickness was studied and compared between steam and $\mathrm{CO}_{2}$ gasification. Zoulalian et al. (2015) proposed model that presents a simple method to handle the evolution of the total surface area and of the reactive surface area. The model was applied to coal and wood char for $\mathrm{O}_{2}$, $\mathrm{CO}_{2}$ and $\mathrm{H}_{2} \mathrm{O}$ gasification experiments (taken from the literature). The experiments were conducted in a thermo balance and an analytical differential fixed bed under gasification conditions with negligible diffusional resistances.

Since 2010, Research and Development Center for Mineral and Coal Technology (Puslitbang tekMIRA) has conducted a research regarding a design for mini gasifier (GasMin). The development of GasMin had been successfully accomplished through changing the reactor diameter and height; it was increase the efficiency to 50\% (Sofaeti, 2013). GasMin is appropriate to be used for substituting oil or LPG in small-scale industries. The investment of GasMin is reasonable and the energy need for smallscale industries is satified. In addition, GasMin is categorized as a clean coal technology as it produces low $\mathrm{NO}_{x}, \mathrm{SO}_{x}$ and particulates (Sofaeti and Daulay, 2014). This paper presents kinetic analysis of coal gasification process in mini gasifier (GasMin) reactor.

\section{METHODOLOGY}

Research of GasMin was conducted at Coal Technology Center, Palimanan - Cirebon, West Java and the simulation of kinetic analysis accomplished at the Laboratory of Research Center for Engineering Science, Gadjah Mada University using the simulation COMSOL. Characteristics of coal used for research were shown in Table 1 . Prior to the kinetic study, reactor condition of the GasMin fixed bed was summarized in Table 2 and schematic diagram of the GasMin coal gasification was shown in Figure 1.

Table 1. Characteristics of coal

\begin{tabular}{lllr}
\hline No. & \multicolumn{1}{c}{ Parameter } & Unit & \multicolumn{1}{c}{ Value } \\
\hline 1 & Proximate & & \\
& Moisture content & $\%$, adb & 16.52 \\
& Ash content & $\%$, adb & 0.83 \\
& Volatile matter & $\%$, adb & 42.22 \\
& Fixed carbon & $\%, a d b$ & 40.43 \\
\hline 2 & Ultimate & & \\
& C & $\%, a d b$ & 67.93 \\
& H & $\%, a d b$ & 6.45 \\
& N & $\%, a d b$ & 0.71 \\
& S & $\%, a d b$ & 0.09 \\
& O & $\%, a d b$ & 23.99 \\
\hline 3 & HHV & $\mathrm{Kkal} / \mathrm{kg}, \mathrm{adb}$ & 5,852 \\
\hline
\end{tabular}


Table 2. Basic experimental condition for gasification

\begin{tabular}{lc}
\hline \multicolumn{1}{c}{ Experimental conditions } & Selected Conditions \\
\hline Reactor type & Fixed bed type, updraft \\
Reactor size & $50 \mathrm{~cm}$ in diameter \\
Reactor high & $120 \mathrm{~cm}$ \\
Capacity & $50 \mathrm{~kg} / \mathrm{h}$ \\
Operating temperature & Approx. $800^{\circ} \mathrm{C}$ \\
Sample size & $2-5 \mathrm{~cm}$ \\
\hline
\end{tabular}

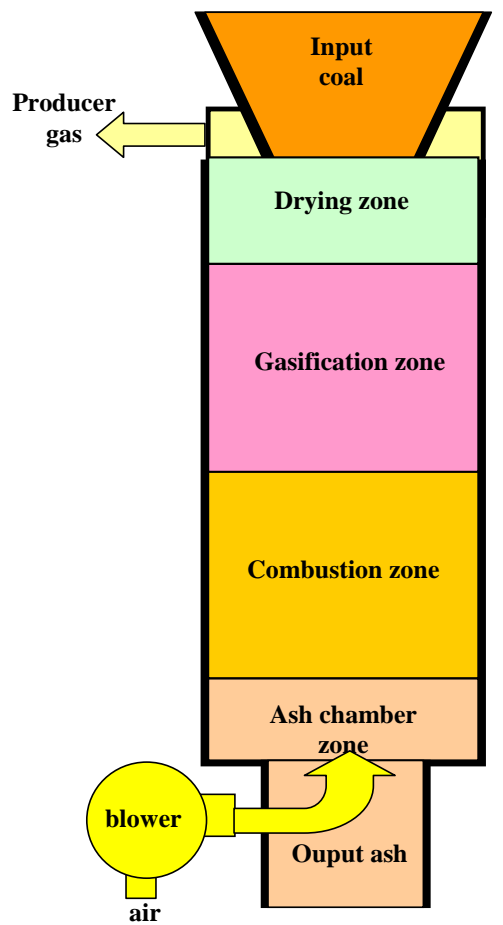

Figure 1. Schematic diagram of GasMin for coal gasification

Coal gasification involves thermal decomposition of coal, reaction of coal carbon and other pyrolysis products with oxygen, water, and fuel gases such as methane (Table 3). In fact, coal gasification is often considered to involving two distinct chemical stages, namely (1) de-volatilization of the coal to produced volatile matter and char followed by (2) char gasification that is complex and specific to the conditions of the reaction. Both processes contribute to the complex kinetics of the gasification process.

The rate of a gasification reaction mainly depends on the reactivity of the fuel and the reaction potential of the gasifying medium. Process temperature and pressure also affect the reaction rates. The combustion reactions are faster than gasification and occur first rapidly to consume the oxygen. Basu (2010) claims that the water-gas reaction is the fastest char reactions while Blasi (2009) states that in gasification, water-gas reaction occurs two to five times faster than the boudouard reaction. An interesting estimation is presented about the relative reaction rates of these three reactions compared to combustion reaction at $800^{\circ} \mathrm{C}$ and $10 \mathrm{kPa}$ overpressure. These rates are presented in Table 4. 
Table 2. Chemical reactions in the coal gasification process

\begin{tabular}{ccc}
\hline Type & Reaction & Enthalpy $(298.15 \mathrm{~K})$ \\
\hline Pyrolysis & $\mathrm{Coal} \rightarrow \mathrm{C}+$ volatile & \\
Gasification & $\mathrm{C}+\mathrm{H}_{2} \mathrm{O}(\mathrm{g}) \rightarrow \mathrm{CO}(\mathrm{g})+\mathrm{H}_{2}(\mathrm{~g})$ & $+131,3 \mathrm{~kJ} /(\mathrm{gmol} \mathrm{C})$ \\
Combustion & $\mathrm{C}+\mathrm{O}_{2}(\mathrm{~g}) \rightarrow \mathrm{CO}_{2}(\mathrm{~g})$ & $-393,5 \mathrm{~kJ} /(\mathrm{gmol} \mathrm{C})$ \\
Hydrogasification & $\mathrm{C}+2 \mathrm{H}_{2}(\mathrm{~g}) \rightarrow \mathrm{CH}_{4}(\mathrm{~g})$ & $-75 \mathrm{~kJ} /(\mathrm{gmol} \mathrm{C})$ \\
Dissociation & $\mathrm{C}+\mathrm{CO}_{2}(\mathrm{~g}) \rightarrow 2 \mathrm{CO}(\mathrm{g})$ & $+172,5 \mathrm{~kJ} /(\mathrm{gmol} \mathrm{C})$ \\
Shift reaction & $\mathrm{CO}(\mathrm{g})+\mathrm{H}_{2} \mathrm{O}(\mathrm{g}) \rightarrow \mathrm{CO}_{2}(\mathrm{~g})+\mathrm{H}_{2}(\mathrm{~g})$ & $-41,2 \mathrm{~kJ} /(\mathrm{gmol} \mathrm{CO})$ \\
Hydrocracking & volatile $+\mathrm{H}_{2}(\mathrm{~g}) \rightarrow \mathrm{CH}_{4}(\mathrm{~g}$ & $-75 \mathrm{~kJ} /(\mathrm{gmol} \mathrm{C})$ \\
Volatile gasification & volatile $+\mathrm{H}_{2} \mathrm{O}(\mathrm{g}) \rightarrow \mathrm{CO}(\mathrm{g})+2 \mathrm{H}_{2}(\mathrm{~g})$ & $+206 \mathrm{~kJ} /\left(\mathrm{gmol} \mathrm{H} \mathrm{H}_{2} \mathrm{O}\right)$ \\
\hline
\end{tabular}

Table 3. Relative reaction rates of four char reactions (Basu, 2010)

\begin{tabular}{cc}
\hline Reaction & Relative reaction rate \\
\hline $\mathrm{C}+1 / 2$ O2 $\rightarrow \mathrm{CO}$ & 105 \\
Water-gas & 103 \\
Boudouard & 102 \\
Methanation & $3 \times 10-3$ \\
\hline
\end{tabular}

The combustion reactions are more than a million times faster than that of other carbon reactions but methanation reaction is quite slow in atmospheric pressure compared to the other reactions, and it is often ignored (Lu and Wang, 2011). The equations for simulation of reaction kinetics of coal gasification were as follows (COMSOL, 2012):

Gasification

$$
R_{B}^{\prime \prime \prime}=k_{B} \varepsilon C_{0} C_{B}\left(\frac{\frac{P \chi_{1}}{R T_{R}}-\left(\frac{P}{R T_{R}}\right)^{2} \frac{\chi_{2} \chi_{3}}{K_{B} C_{1}}}{1+\frac{P}{R T_{R}}\left(\gamma_{1 C} \chi_{1}+\gamma_{2 C} \chi_{2}+\gamma_{3 C} \chi_{3}\right)}\right)
$$

Combustion

$$
R_{C}^{\prime \prime \prime}=\frac{k_{C} \varepsilon C_{C} \frac{P}{R T_{R}}\left(\chi_{4}-\frac{\chi_{5}}{K_{C} C_{1}}\right)}{1+\frac{P}{R T_{R}}\left(\gamma_{4 C} \chi_{4}+\gamma_{5 C} \chi_{5}\right)}
$$

Hydrogasification

$$
R_{D}^{\prime \prime \prime}=k_{D} \varepsilon C_{0} C_{D}\left(\frac{\left(\frac{P}{R T_{R}}\right)^{2} \chi_{3}^{2}-\frac{P}{R T_{R}} \frac{\chi_{6}}{K_{D} C_{1}}}{1+\frac{P}{R T_{R}}\left(\gamma_{3 C} \chi_{3}+\gamma_{6 C} \chi_{6}\right)}\right)
$$

Dissociation

$$
R_{E}^{\prime \prime \prime}=k_{E} \varepsilon C_{0} C_{E}\left(\frac{\frac{P \chi_{5}}{R T_{R}}-\left(\frac{P}{R T_{R}}\right)^{2} \frac{\chi_{2}^{2}}{K_{E} C_{1}}}{1+\frac{P}{R T_{R}}\left(\gamma_{5 C} \chi_{5}+\gamma_{2 C} \chi_{2}\right)}\right)
$$

Shift Reaction

$$
R_{F}^{\prime \prime \prime}=k_{F} \varepsilon\left(\frac{P}{R T_{R}}\right)^{2}\left(\chi_{1} \chi_{2}-\frac{\chi_{3} \chi_{5}}{K_{F} C_{1}}\right)
$$


Hydrocracking

$$
R_{G}^{\prime \prime \prime}=k_{G} \varepsilon C_{0} C_{G}\left(\frac{\left(\frac{P}{R T_{R}}\right)^{2} \chi_{3}^{2}-\frac{P}{R T_{R}} \frac{\chi_{6}}{K_{G} C_{1}}}{1+\frac{P}{R T_{R}}\left(\gamma_{3 V} \chi_{3}+\gamma_{6 V} \chi_{6}\right)}\right)
$$

Volatile gasification

$$
R_{H}^{\prime \prime \prime}=k_{H} \varepsilon C_{0} C_{H}\left(\frac{\frac{P \chi_{1}}{R T_{R}}-\left(\frac{P}{R T_{R}}\right)^{3} \frac{\chi_{2} \chi_{3}^{2}}{K_{H} C_{1}}}{1+\frac{P}{R T_{R}}\left(\gamma_{1 V} \chi_{1}+\gamma_{2 V} \chi_{2}+\gamma_{3 V} \chi_{3}\right)}\right)
$$

$\mathrm{P} \quad=$ gas pressure

$\mathrm{R}=$ universal gas constant,

$\mathrm{T}_{\mathrm{R}}=$ reactor temperature

$\mathrm{k}_{\mathrm{B}}=$ reaction rate coefficient $\mathrm{H}_{2} \mathrm{O}$ with coal

$\mathrm{k}_{\mathrm{H}}=$ the reaction rate coefficient $\mathrm{H}_{2} \mathrm{O}$ with volatile matters,

$\mathrm{k}_{\mathrm{C}}=$ the reaction rate coefficients $\mathrm{O}_{2}$ with coal,

$\mathrm{k}_{\mathrm{D}}=$ hydrogen reaction rate coefficients with coal

$\mathrm{k}_{\mathrm{G}}=$ hydrogen reaction rate coefficients with volatile matters,

$\mathrm{k}_{\mathrm{E}}=\mathrm{CO}_{2}$ reaction rate coefficients with coal,

$\mathrm{k}_{\mathrm{F}}=$ reaction rate coefficients shift.

$\gamma_{1 \mathrm{C}}=$ absorption coefficient of $\mathrm{H}_{2} \mathrm{O}$ on the surface of coal

$\gamma_{2 c}=$ mass transfer coefficient equilibrium $\mathrm{CO}$ on the surface of coal

$\gamma_{3 c}=$ equilibrium mass transfer coefficient on the surface of coal

$\gamma_{4 C}=$ equilibrium coefficient of mass transfer of $\mathrm{O}_{2}$ on the surface of coal.

$\gamma_{5 c}=$ equilibrium coefficient of mass transfer of $\mathrm{CO}_{2}$ on the surface of coal.

$\gamma_{6 \mathrm{C}}=$ coefficient of $\mathrm{CO}_{2}$ adsorption on the surface of coal

$\gamma_{1 v}=$ absorption coefficient of $\mathrm{H}_{2} \mathrm{O}$ on the surface of volatile matters.

$\gamma_{2 v}=$ mass transfer coefficient equilibrium $\mathrm{CO}$ on the surface of volatile matters

$\gamma_{3 V}=$ equilibrium mass transfer coefficient on the surface volatile matters.

$\gamma_{4 \mathrm{~V}}=$ each is equilibrium mass transfer coefficient $\mathrm{H}_{2}$ at the surface of the volatile matters.

$\gamma_{5 v}=$ each is the mass transfer coefficient equilibrium $\mathrm{CO}$ and $\mathrm{CO}_{2}$ on the surface of coal.

$\gamma_{6 \mathrm{~V}}=$ each is equilibrium mass transfer coefficient $\mathrm{H}_{2}$ and $\mathrm{CO}_{2}$ at the surface of the volatile matters.

The values of these parameters depend on the reactor temperature and the coal surface reactivity against $\mathrm{H}_{2} \mathrm{O}, \mathrm{CO}, \mathrm{H}_{2}, \mathrm{O}_{2}$ and $\mathrm{CO}_{2}$ as well. The relations between reaction rate coefficient $(k)$ and equilibrium coefficient $(K)$ with the temperature is stated according to the Arrhenius equation.

\section{RESULTS AND DISCUSSION}

\section{Reaction Kinetics of the GasMin}

Figure 2 shows that the molar flow rate of oxygen decreased rapidly at approximately 0.2 meters from the input of the reactor, instead of $\mathrm{CO}_{2}$ that increased rapidly in the same range. It shows that the approximately 0.2 meters from the reactor input stands for the combustion zone. In this zone, the oxygen reacts with coal to produce $\mathrm{CO}_{2}$ gas. Meanwhile, the 0.0-0.2 $\mathrm{m}$ serves as the ash chamber zone. No reaction occurs in this zone. Coal combustion is an exothermic reaction result in increasing the reactor temperature. The rate of gasification reaction increases along with the increase of reactor temperature. Gasification reaction rate has a maximum value at the end of the combustion zone when the temperature of the gas inside the reactor reaches the maximum value. 


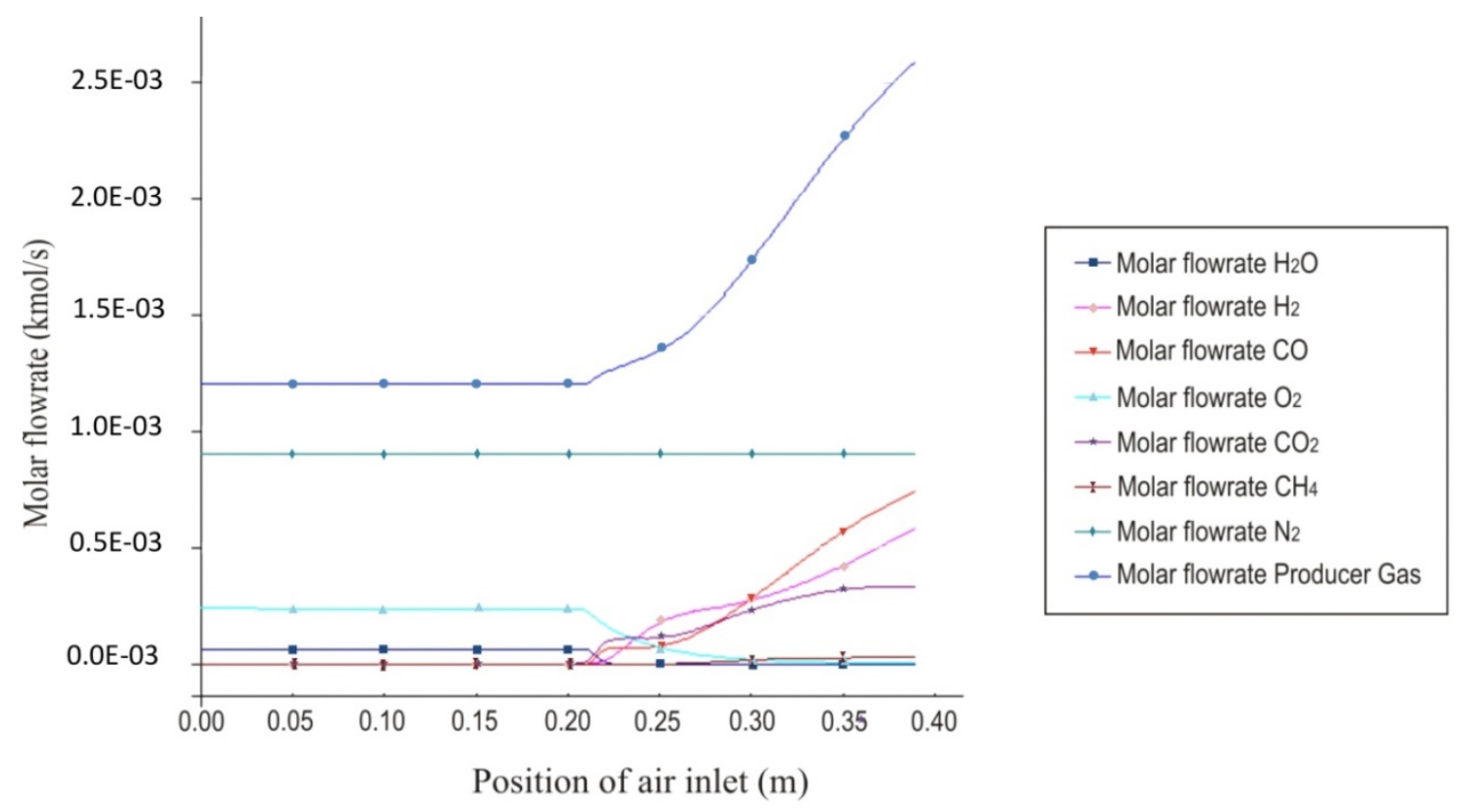

Figure 2. Axial distribution of the gas flow rate in the reactor

Figure 2 also shows the increase in the molar flow rate of hydrogen $\left(\mathrm{H}_{2}\right)$ and carbon monoxide (CO). Meanwhile, the molar flow rate of $\mathrm{CO}_{2}$ and $\mathrm{H}_{2} \mathrm{O}$ has decreased as a result of the gasification reaction. The total amount of gas molar flow rate increases due to the formation of compounds of gas because of coal gasification reaction. This initial calculation made with assumption the reactor was adiabatic. In other words, the wall of reactor was considered perfectly insulated so there was no heat flow through. Thus, the gasification reaction stopped when the reaction equilibrium was achieved. At equilibrium, the reactor temperature and gas composition values were constant against the axial position of the input reactor. The results show that the gas output of reactor was dominated by $\mathrm{CO}$ with $26.72 \%$ mole fraction; $\mathrm{H}_{2}$ with $14.06 \%$ mole fraction, and $\mathrm{N}_{2}$ with $47.88 \%$ mole fraction. Meanwhile $\mathrm{CO}_{2}$ mole fraction was $5 \%, \mathrm{CH}_{4}$ mole fraction was $0.24 \%$ and $\mathrm{O}_{2}$ mole fraction was $1.20 \%$.

\section{Effect of Inlet Air Position on Distribution of Axial Temperature in the Reactor}

Figure 3 shows that the maximum temperature of the reactor was not affected by the inlet air temperature. Changing the temperature of the inlet air $\left(\mathrm{T}_{\mathrm{ia}}\right)$ has a consequence in shifting combustion zone.
This also affects the condition of producer gas. Increasing the $\mathrm{T}_{\mathrm{ia}}$ will shift the combustion zone more upward of the reactor as shown in Figure 1 because the pressure and the volume of the input air also increase. As a result, gasification reaction becomes imperfect if the reactor is not long enough. Thus if the ACR is 2.4 and $T_{\text {ia }}$ is $100^{\circ} \mathrm{C}$, the combustion zone must be at least $0.25 \mathrm{~m}$ from the bottom of the reactor.

Figure 4 shows effect of inlet air temperature on some important components producer gas $\left(\mathrm{CO}, \mathrm{H}_{2}, \mathrm{CH}_{4}\right.$ and $\left.\mathrm{CO}_{2}\right)$, the gas mass flow rate, calorific value gas, and producer gas energy. The heating value was calculated based on producer gas components that can be burned. Thus, the calorific value (q-value; in units of $\mathrm{kJ} / \mathrm{gmol}$ ) can be calculated by equation (8).

q-value $=X_{1} L_{H} V_{1}+X_{2} L_{H} V_{2}+X_{3} L_{H} V_{3}$

$\mathrm{LHV}_{1}, \mathrm{LHV}_{2}$, and $\mathrm{LHV}_{3}$ each is a lower calorific value of combustion of $\mathrm{CO}, \mathrm{H}_{2}$, and $\mathrm{CH}_{4}$. Energy on producer gas ( $\mathrm{Q}$, in units $\mathrm{kW}$ ) can be calculated with mass flow of producer gas $\left(\mathrm{M}_{\mathrm{G}}\right)$ and calorific value (equation 9).

$\mathrm{Q}=\mathrm{M}_{\mathrm{G}} \times(\mathrm{q}$-value $)$ 


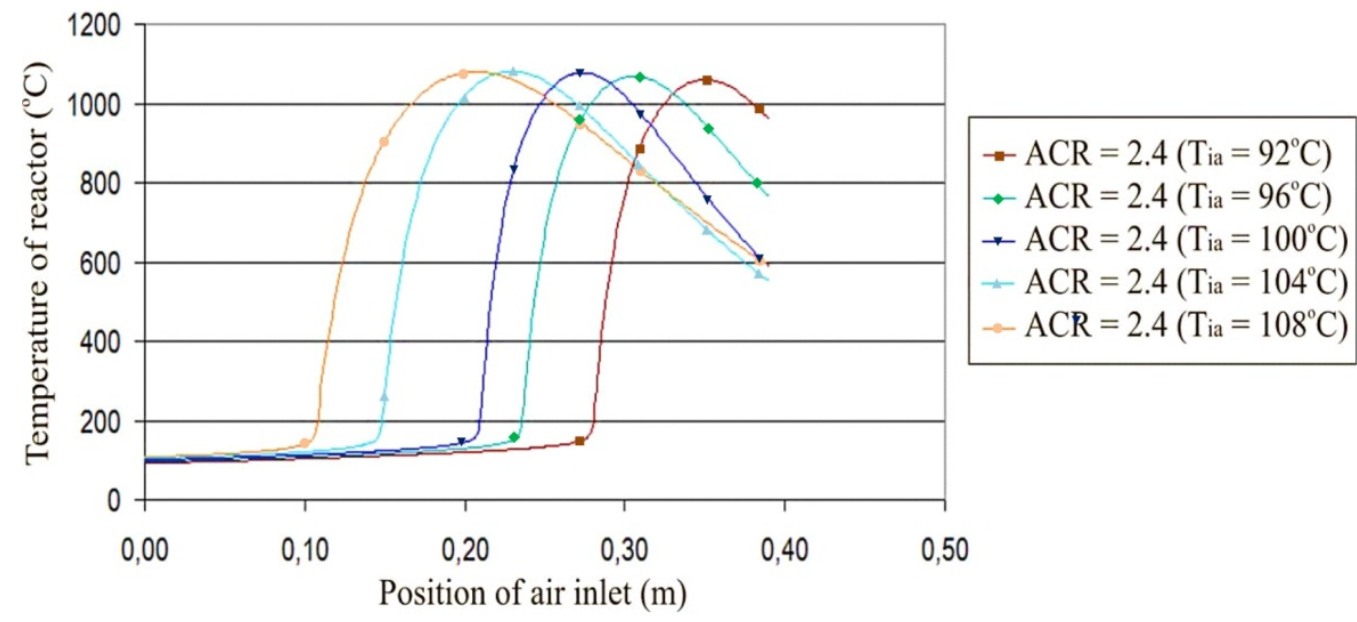

Figure 3. Effect of inlet air position on distribution of axial temperature in the reactor with fixed air-coal ratio and temperature of input air $\left(T_{i a}\right)$ variation

$M_{G}$ mole fractions increases with the increase of air temperature entering reactor. Meanwhile the mole fraction of $\mathrm{CO}_{2}$ decreases. An increase in the mole fraction of $\mathrm{CO}$ and $\mathrm{CH}_{4}$ indicates that the gasification reaction increases dominantly. The high mole fraction of $\mathrm{CO}_{2}$ indicates that the combustion reaction remains high. Gasification reaction shown by high temperature of the entering reactor air is also indicated from the higher gas molar flow rate.

\section{Effect of Variation the Air-Coal Ratio}

Flow rate of the coal mass is expected to remain at $50 \mathrm{~kg} /$ hour. Thus, if the ACR is 3 , the air mass flow rate should be150 kg / hour. Figure 5 shows the correlations between the axial temperature distribution without value adjustments and the ACR at a constant inlet air temperature in the reactor. In this case, the value of inlet air temperature reactor $\left(\mathrm{T}_{\mathrm{ia}}\right)$ is assumed to be fixed at $100{ }^{\circ} \mathrm{C}$.

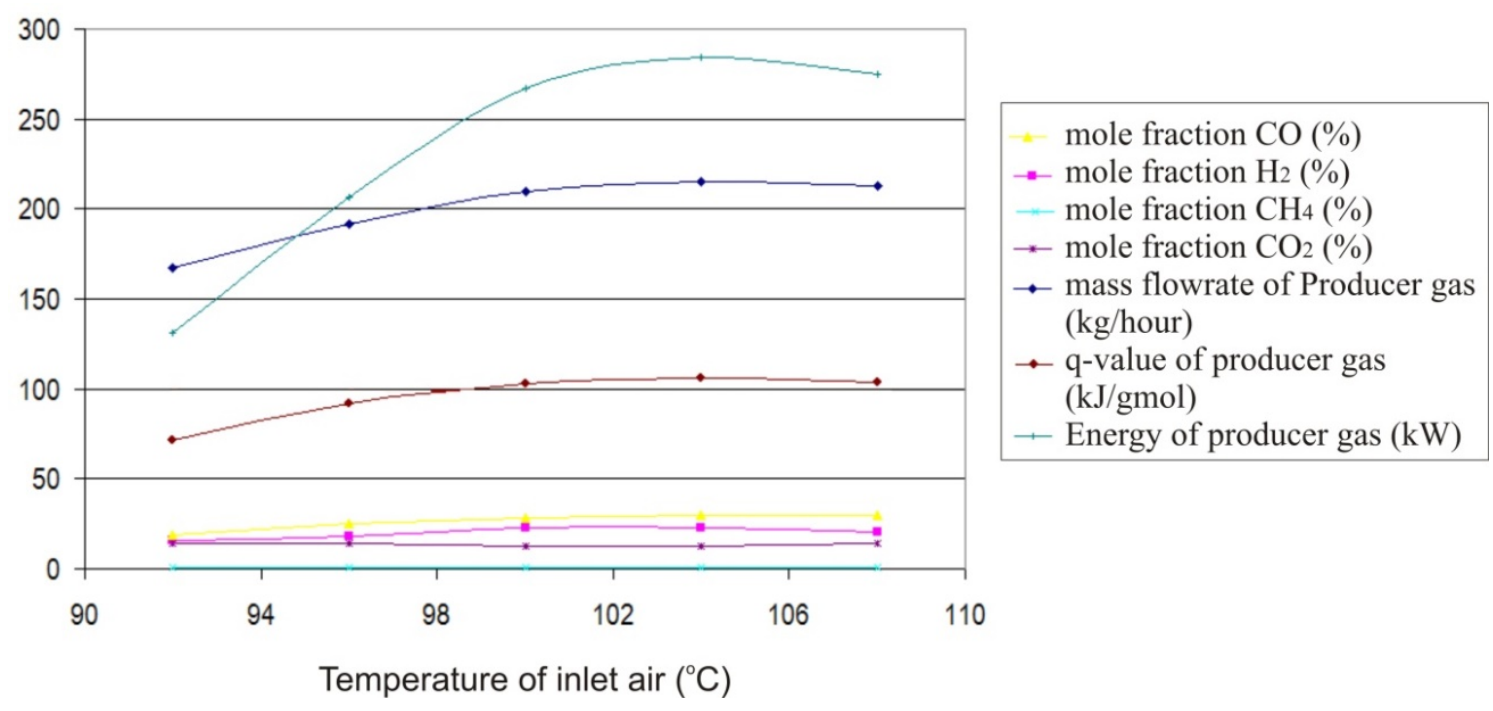

Figure 4. Effect of inlet air temperature on the components of gasification in the reactor 


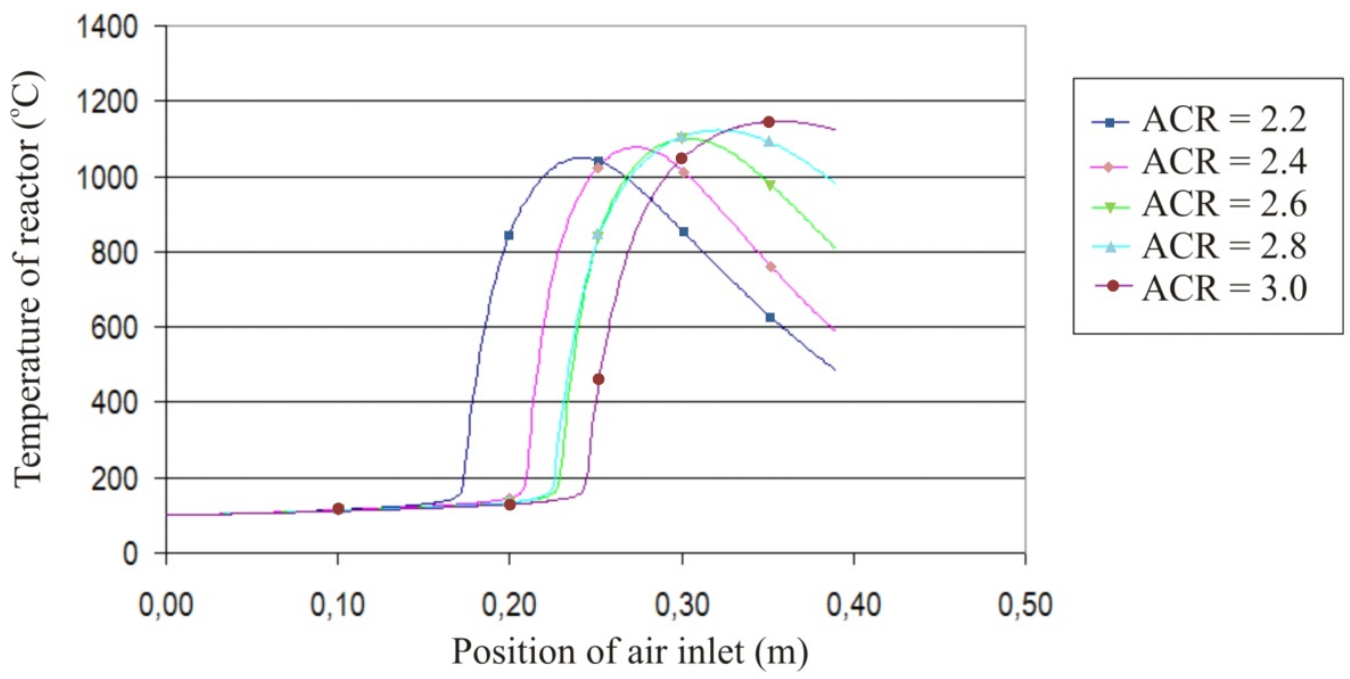

Figure 5. Effect of inlet position for the distribution of axial temperature in the reactor (with fixed temperature of input air, air-coal ratio variation)

The increase of the ACR affects the maximum temperature of the reactor as the increase in the intake air flow rate will also increase the amount of oxygen for establishing combustion reaction. Thereby, the amount of coal combustion reaction increases resulted in increasing the maximum reactor temperature. Figure 5 also shows the increase of ACR effect on the increase of air inlet position and combustion zone shift. Due to the addition of air flow rate, while the volume that passes through the fixed inlet results in the pressure of the air flow rate increases and the position of the air inlet shifts to the right side. It should be considered when designing the reactor to have enough space for reactions of the oxidation and reduction.

Figure 6 shows the correlation among mole fraction some important components of gasification $\left(\mathrm{CO}, \mathrm{H}_{2}, \mathrm{CH}_{4}\right.$ and $\mathrm{CO}_{2}$ ), flow rate of producer gas, calorific value of producer gas and energy of producer gas as well as the flowing ACR.

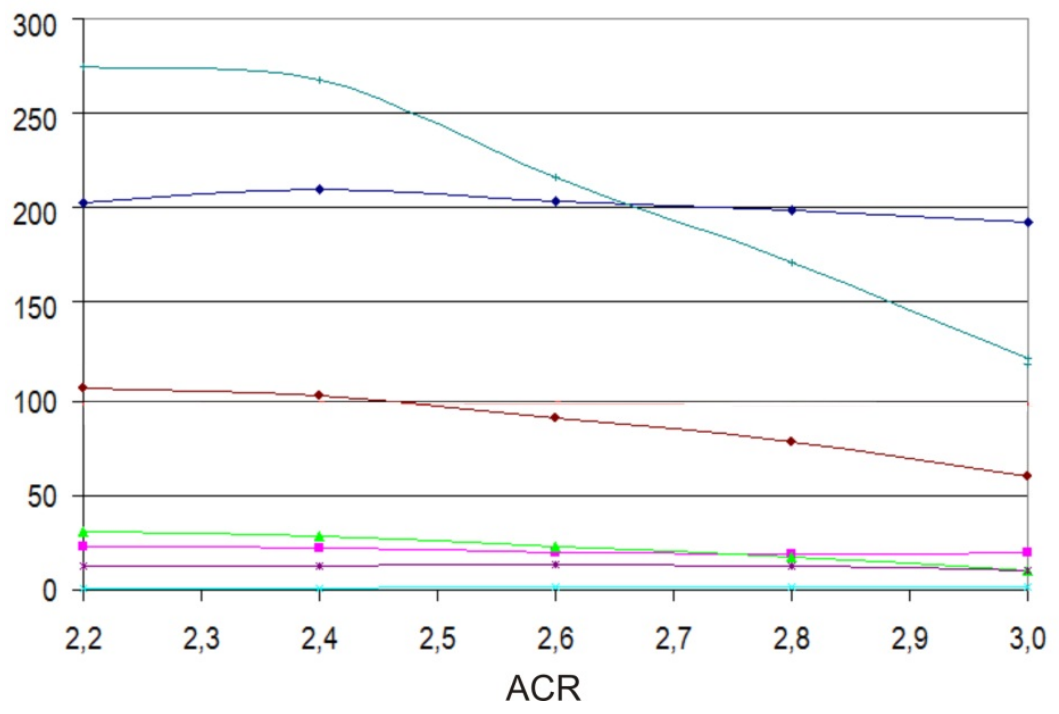

\footnotetext{
- mole fraction $\mathrm{CO}(\%)$

- mole fraction $\mathrm{H}_{2}(\%)$

* mole fraction $\mathrm{CH}_{4}(\%)$

$*$ mole fraction $\mathrm{CO}_{2}(\%)$

$\rightarrow$ mass flowrate of producer gas (kg/hour)

$\rightarrow$ q-value of producer gas $(\mathrm{kJ} / \mathrm{gmol})$

$\rightarrow$ Energy of producer gas $(\mathrm{kW})$
}

Figure 6. Effect of air-coal ratio (ACR) on the components of gasification within reactor 
The mole fraction of $\mathrm{CO}$ reduced when ACR increased. This means that the increase of ACR value in line with combustion on the gasification. Another symptom of decline rate gasification process is the mole fraction of $\mathrm{H}_{2}$ and $\mathrm{CH}_{4}$ is slightly reduced by the increase of the ACR value. The gasification decreases causes calorific value (q-value) of producer gas as well as the energy of producer gas were reduced. According to equations 1 and 2, all oxygen reacts with carbon results in unnecessary addition of the ACR value increased combustion reaction rather than gasification.

\section{Effect of Variation the Steam-Coal Ratio}

Inlet air flow rate was assumed to be fixed at $120 \mathrm{~kg} / \mathrm{h}$ and the coal mass flow rate was 50 $\mathrm{kg} / \mathrm{h}$. It meant that Steam-Coal Ratio (SCR) $=2.4$. The flow rate of water vapors varied from 0 up to $8 \mathrm{~kg} /$ hour meaning that SCR values varied from 0 to 0.16 . Figure 7 shows the correlation axial temperature distribution of the ACR. The value of inlet air temperature reactor $\left(\mathrm{T}_{\mathrm{ia}}\right)$ was assumed to be fixed at $100^{\circ} \mathrm{C}$.

Increasing the SCR value would lessen the maximum reactor temperature due to the increase value in SCR that resulted in the increase of steam amount that occurred within the air inlet. As a result, the steam increase would improve the reaction of gasification.

Figure 8 showed the relation among mole fraction of some important gasification components $\left(\mathrm{CO}, \mathrm{H}_{2}, \mathrm{CH}_{4}\right.$ and $\left.\mathrm{CO}_{2}\right)$, flow rate of producer gas, calorific value of producer gas, and energy of producer gas to the SCR. It showed that the increase of SCR value slightly increased the $\mathrm{CO}$ mole fraction of producer gas. It occurred because the increase of the SCR would-increase the amount of steam and enhanced the gasification. When the value of SCR increased, the increase in the mole fraction of $\mathrm{CO}$ led to an increase in calorific value (qvalue) and energy of producer gas.

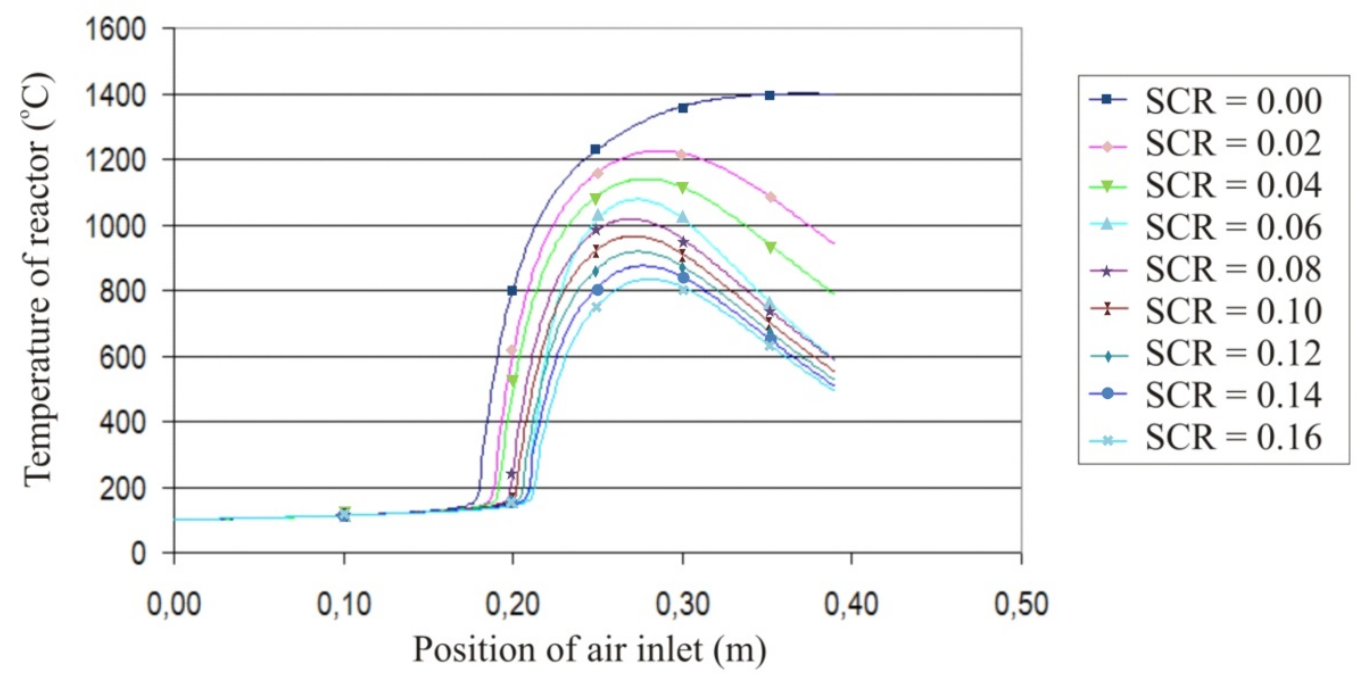

Figure 7. Effect of inlet air temperature on the distribution of axial temperature in the reactor (with fixed temperature of input air, steam-coal ratio variation) 


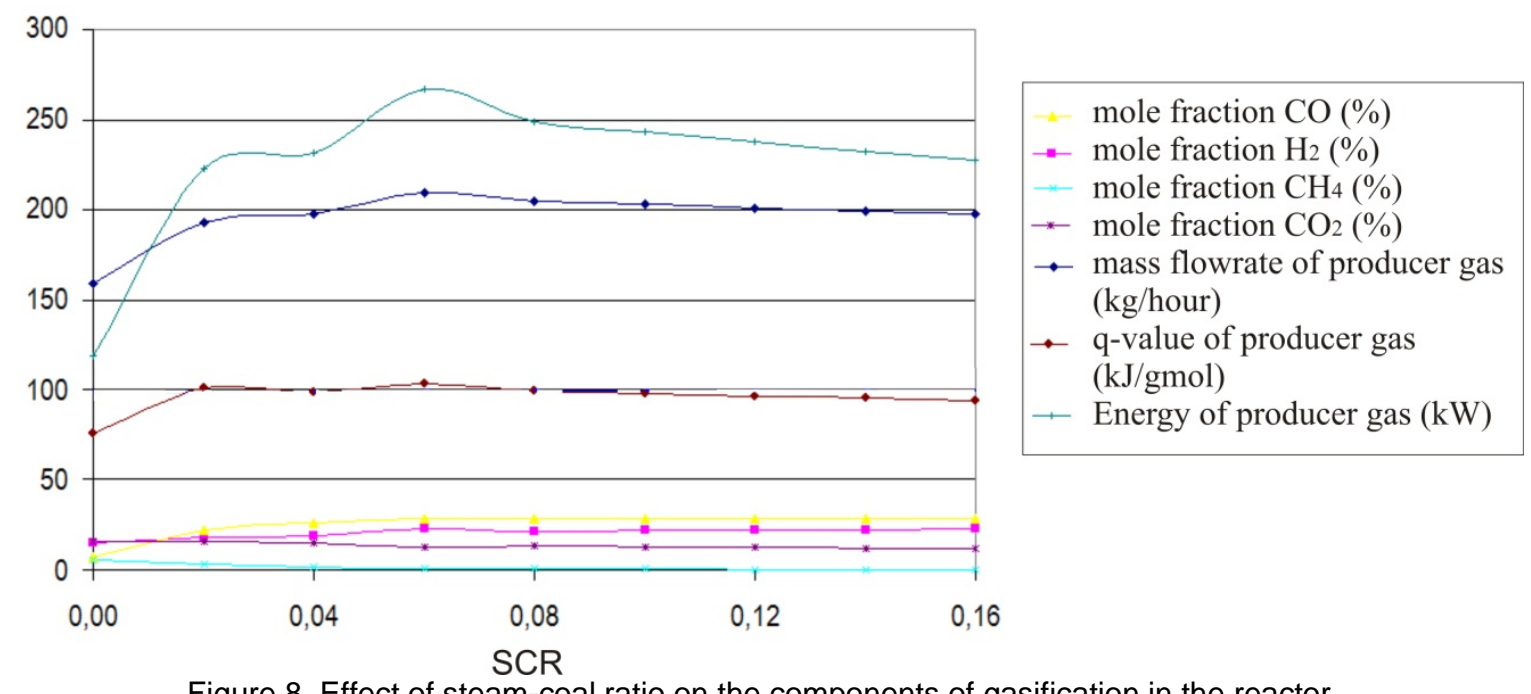

Figure 8. Effect of steam-coal ratio on the components of gasification in the reactor

At fixed air flow rate, increasing the SCR would increase the total flow rate of the airsteam mixture in reactant, therefore the ability to gasify of coal also increased. This led to increase the gasification efficiency, about $3-5 \%$. As a result, the gas yield increased. The maximum value of SCR was 0.06 , bigger than that such a figure, the yield gas and energy of producer gas will decrease. This occurred because the energy from the combustion decreased and would decrease the fulfillment of energy needs for gasification.

\section{CONCLUSIONS}

Simulation of chemical reaction shows that the reactor gas output dominated by $\mathrm{CO}$ (26.72\% mole fraction), $\mathrm{H}_{2}$ (14.06\% mole fraction), and $\mathrm{N}_{2}$ (47.88\% mole fraction). Meanwhile $\mathrm{CO}_{2}$ mole fraction is $5 \%, \mathrm{CH}_{4}$ mole fraction is $0.24 \%$ and $\mathrm{O}_{2}$ mole fraction is $1.20 \%$. These results are similar with the field experiment of GasMin. The result also shows that the inlet air temperature did not affect the maximum temperature of reaction. The increase of the ACR enlarged the maximum reactor temperature as the increase of the incoming air flow rate was used for establishing combustion reaction. The SCR increased the total flow rate of the air-steam mixture feed; therefore the ability to gasification of coal had also improved. This led to the increase of gasification efficiency, about 3-5\%. This in turn would increase the yield gas. The maximum value of SCR was 0.06. If bigger than that such a figure, the yield gas and energy of producer gas would decrease.

\section{ACKNOWLEDGEMENTS}

The authors wish to express sincere gratitude to the Head R\&D Center for Mineral and Coal Technology for the support and assistance for conducting this project. The authors would also like to acknowledge the technicians, researchers and engineers of the GasMin team for their help during the project. Acknowledge and appreciation to Research Center for Engineering Science, Gadjah Mada University for their advice and assistance.

\section{REFERENCES}

Basu, P. 2010. Biomass Gasification Design Handbook. Elsevier Inc. ISBN 978-012-374988-8.

Blasi, D., Colomba. 2009. Combustion and gasification rates of lignocellulosic chars. Progress in Energy and Combustion Science, 35, p. 121-140.

COMSOL, COMSOL Multiphysics Modeling Guide, version 4.2, 2012.

Gomez, A. and Mahinpey, N., 2015. Kinetic study of coal steam and $\mathrm{CO}_{2}$ gasification: A new method to reduce interparticle diffusion. FUEL, 148, p.160-167. 
He, C., Feng, X., and Hoong, K., 2013. Process modeling and thermodynamic analysis of Lurgi fixed-bed coal gasifier in an SNG plant. Applied Energy, 111, p. 742-757.

Jang, D., Kim, H., Lee, C., and Kim, S., 2013. Kinetic analysis of catalytic coal gasification process in fixed bed condition using Aspen Plus. International Journal of Hydrogen Energy, 38(14), p. 6021-6026.

Lu, X., and Wang, T., 2011. Water-gas Shift Modeling of Coal Gasification in an Entrained-Flow Gasifier. In Proceedings of the 28th International Pittsburgh Coal Conference, September 12-15, Pittsburg, PA, USA, p. 45.

Skodras, G., Nenes, G. and Zafeiriou, N., 2015. Low rank coal- $\mathrm{CO}_{2}$ gasification: Experimental study, analysis of the kinetic parameters by Weibull distribution and compensation effect. Applied Thermal Engineering, 74, p.111-118.

Slavinskaya, N. A., Petrea, D. M., and Riedel, U., 2009. Chemical kinetic modeling in coal gasification overview. In Proceedings of the 5th international workshop on plasma assisted combustion (IWEPAC), Alexandria, Virginia.
Sofaeti,Y., 2013. Pengembangan Rancang Bangun Gasifier Batubara Mini untuk Menunjang Ketersediaan Energi di UKM dan Pengganti BBM pada Mesin Generator Listrik 1 kW. Laporan Teknik, Puslitbang Teknologi Mineral dan Batubara.

Sofaeti,Y., and Daulay, B., 2014, Mini Coal Gasifier for Fulfilling Energy Consumption in Small Scale Industries. Proceedings of the 1st International Conference on Energy and 7th Indonesia - Malaysia Geoheritage Conference, Yogyakarta. ISBN 978602-8461-28-3.

Speight, J. G., 2013a. The chemistry and technology of coal (3rd ed.). Boca Raton, Florida: CRC Press, Taylor \& Francis Group.

Speight, J. G., 2013b. Coal-fired power generation handbook. Salem, Massachusetts: Scrivener Publishing.

Speight, J.G., 2015. 5 - Gasification reaction kinetics for synthetic liquid fuel production, Copyright 2015 Woodhead Publishing Limited. All rights reserved.

Zoulalian, A., Bounaceur, R. and Dufour, A., 2015. Kinetic modelling of char gasification by accounting for the evolution of the reactive surface area. Chemical Engineering Science, 138, p.281-290. 
